\title{
Terminal Illness Counselling by Psychiatric Nurse
}

\author{
Bushra Mushtaq* \\ P.G Psychiatry Nursing Scholar, India
}

Submission: June 27, 2018; Published: July 26, 2018

*Corresponding author: Bushra Mushtaq, P.G Psychiatry Nursing Scholar, India, Email: bushra.mushtaq77@gmail.com

\section{Terminal Illness}

A disease that cannot be cured and which may result in death within the limited time.

\section{Counsellor must have following abilities}

a) Must understand the illness experienced by the client.

b) Should completely perceive that the experience is unique to the client.

c) Build a healthy therapeutic alliance and relation with the client.

d) Increase self-awareness.

e) Must have communication skills like listening, verbal, non-verbal communication.

f) Must provide conducive environment to the client.

g) Keeps goals clear in mind.

h) Being non-judgemental.

i) Avoid jumping to conclusion.

j) Being un-biased.

Counsellors have to provide supportive environment to the client and has to counsel to client through each stage which is stated as below:

\section{Stage 1: Denial and Isolation}

a) Continuous education to the client is provided and all the positive energy present may be driven towards health aspect,

b) Try to make the client more busy and mingle with the family and friends. c) Try to alleviate the sufferings.

\section{Stage 2: Anger}

a) Allow the client to outburst anger which may be give them relief.

b) Try to involve client's family and friends in the interaction and educate them fully about the anger of the client.

c) Always ensure the client that family members are with them in this situation.

\section{Stage 3: Bargaining}

a) Encourage the client to speak.

b) Neither reject the Bargains nor accept them.

\section{Stage 4: Depression}

a) Try to keep client all time interactive and busy.

b) Maintain the good rapport with the client so that client shares his feelings very easily.

c) Avoid any triggering factor which may worse the situation.

d) Ensure that the patients are well groomed.

e) Active listening can play an important part.

\section{Stage 5: Acceptance}

a) Ensure support to the client whenever they are in need.

b) Support and counsel the client continuously.

c) Maintain a positive and health interaction. 


\section{Your next submission with Juniper Publishers} will reach you the below assets

- Quality Editorial service

- Swift Peer Review

- Reprints availability

- E-prints Service

- Manuscript Podcast for convenient understanding

- Global attainment for your research

- Manuscript accessibility in different formats

( Pdf, E-pub, Full Text, Audio)

- Unceasing customer service

Track the below URL for one-step submission https://juniperpublishers.com/online-submission.php 